\title{
Views on the Current Situation of Economics Teaching and Research in Colleges and Universities
}

\author{
Guangdong Youth Vocational College 510507 \\ Hu Zhangming \\ Item Number: CQ20160407
}

\section{Keywords: Colleges and Universities; Economics; Teaching; Research}

\begin{abstract}
Marxist economics and Western economics are all part of the economics teaching of colleges and universities. How to deal with the relationship between the two different economic system, how to arrange in the curriculum system, how to develop the actual teaching process, etc. The main problems that need to be solved in the process of teaching and researching economics in colleges and universities. This paper will first briefly discuss the current situation of teaching and research in this subject, and then analyze the main reasons of problems in the course of economics related courses in colleges and universities, and finally make recommendations based on these issues.
\end{abstract}

\section{Introduction}

Since the reform and opening up policy has been used nearly 40 years, China's economy has developed substantially. In this process, Western economics and related theories have gradually gained wider recognition. For the issues discussed in this paper, the development of the teaching and research of economics in universities has also been affected. In the traditional teaching process, Marxist economics has always been a major component of economics teaching content, and with the increasing application of Western economics in the market, universities also target the original teaching system and research methods. Adjustments have been made, and some colleges and universities have even completely abolished courses such as Capital and replaced them with Western economics courses. If we can't regulate this situation, let Marxist economics be further marginalized in colleges and universities. It is difficult for students to use the relevant courses of economics to understand and grasp the socialist economic system and to recognize the law of social economic development. In order to avoid such a situation, this paper will study the solution based on the analysis of the causes of this situation.

\section{The Status Quo of Economics Teaching and Research in Chinese Universities}

\subsection{Marxist Economics is Gradually Marginalized}

With the continuous development of our society, Western economics and related theories have gained more recognition in this process. Most universities have established relevant courses to ensure that students can effectively master these theories, but the market economy continues to deepen. Under the background, the main position of Marxist economics in the economics curriculum system of colleges and universities has also been greatly threatened. Some colleges and universities even choose to abolish the courses related to Marxist economics and only offer Western economics courses. Obviously, such curriculum setting method is not scientific. Colleges and universities should be able to adjust the existing curriculum to ensure that two different economic theory systems can be involved in the teaching and research process of colleges and universities.

\subsection{Students Cannot Acquire Relevant Knowledge and Skills from the Economics Teaching Process}

College students are more susceptible to emerging ideas in practical teaching and life [1]. Students in the process of learning have despised Marxist economics and paid too much attention to the status of Western economics. In this context, students' values, the world outlook, outlook on life, etc. 
may all be affected by this, and gradually form the psychology of capital only in Western economics. On the other hand, teachers' attention to Marxist economics related courses also has a certain downward trend. In the process of teaching and research, they pay more attention to Western economics and related thoughts, which ultimately leads to the failure of Marxist economics teaching in college economics and play the original role in the research process.

\section{Causes of the Problem}

\subsection{Market Economy Poses New Challenges to Marxist Economics}

With the help of the market economic system, China's economic situation has been greatly improved, and this economic system has also had a certain impact on the operation methods of enterprises and the government's regulation and control functions on the market [2]. Under such a background, if Marxist economics cannot solve the problems existing in the current situation of China's multiple ownership economy and the coexistence of multiple modes of distribution, then this discipline and related theories will inevitably be gradually eliminated by market and society. Such a situation reflected in the university will directly evolve into a significant reduction in the proportion of the curriculum system.I

\subsection{Social Critical Thoughts on Marxist Economics}

Under the influence of Western economics, some scholars and officials only saw the benefits that such thoughts and theoretical systems can bring, while ignoring the consideration of China's actual national conditions, and publishing a large number of critical Marxist economics in the society. The remarks, obviously, such an atmosphere will inevitably have an impact on the development of economics teaching and research in universities, which will eventually lead to the marginalization of Marxist economics in colleges and universities.

\subsection{The Textbooks of Marxist Economics in Colleges and Universities are Not Close Enough to Modern Economic Issues}

Compared with the above content, the problem reflected in the textbook is subjective. It is not difficult to find out the existing Marxist economics related textbooks. These textbooks are more focused on the ideological guidance and the attributes as tool are weaker. The characteristics will directly lead students to think wrongly as Marxist economics. It can only be advertised ideologically, but it cannot solve actual economic problems [3]. With the continuous development of society, Marxist economics itself has also undergone certain changes. However, if the textbook layout is difficult to be close to modern economics, then students' interest in learning, teachers' enthusiasm on teaching and research may be affected by this.

\section{Improve Strategy}

\subsection{The Education Department Should Clarify the Guiding Position of Marxist Economics in The Economics of Colleges and Universities}

The education department should regulate the existing curriculum system of college economics from the following aspects: 1. Evaluate the school-running situation of economics-related majors in universities. In this process, the education department should measure the proportion of Marxist economics courses in the overall economics curriculum in colleges and universities. If there is a situation in which the proportion is too small or the scores are small, the relevant responsible personnel should be urged to make the relevant personnel as soon as possible to improve. 2 . Examine and evaluate the research direction of master's and doctoral degrees in economics. Colleges and universities are the main channels for delivering high-quality talents to the society. Some universities with master's degree in political economy and doctoral authorization do not actually provide teaching and research directions with Marxist economics as the main research content. The education department should target such situations and so supervise and rectify. 


\subsection{Doing the Integration of Marxist Economics and Western Economics in the Teaching System of Colleges and Universities}

Marxist economics and some of the theories and viewpoints in Western economics are actually opposite [4]. Therefore, universities must recognize this in the process of integrating the two, avoiding the two theoretical systems. Complete integration has a negative effect on the actual teaching and research process. In the course of this work, relevant teachers and researchers of universities should start from the following points:

(1) Effective use of analytical tools in Western economics. As mentioned above, the inability of Marxist economics to analyze modern economic issues is one of the main reasons for the gradual marginalization of this discipline in universities. Therefore, relevant teachers and researchers in universities can learn from Western economics. In the analysis tool part, this part of the content is quoted in the teaching process to ensure that Marxist economics can better cope with the development trend of China's market economic system.

(2) Under the guidance of Marxism, the teaching and research of Western economics is carried out. In order to ensure that the training of financial professionals in colleges and universities can meet the needs of the society, the teaching of Western economic theories and ideas is indispensable. In combination with the issues discussed in this paper, the development of these courses should also be completed under the guidance of Marxism. In turn, the theoretical basis of Marxist economics in economics is played to ensure that the development of Western economics teaching and research processes is in line with China's national conditions.

\subsection{Reforming the Development of Marxist economics Teaching Process from the Aspects of Teachers and Teaching Materials}

First of all, from the perspective of teachers, colleges and universities should be able to absorb more teachers who have deeper abilities in teaching Marxist economics and higher levels of teaching, and ensure that the development of courses related to Marxist economics can better attract students' attention. Students can also communicate better in the classroom.

Secondly, from the perspective of teaching materials, this part of the textbook should effectively absorb the development and innovation of Marxist economics on the basis of the original, and at the same time introduce appropriate domestic and foreign scholars' new research results on Marxist economics. Under such a background. The development of courses related to Marxist economics will inevitably better meet the development needs of China's economy.

\section{Conclusion}

In summary, the impact of Western economics on Marxist economics is a major issue in the teaching and research of economics in colleges and universities. To avoid the impact of these problems on the actual teaching effects and research process, relevant units and responsible persons should be clear. The guiding position of Marxist economics, the effective integration of Marxist economics and Western economics, and the reform of college teachers and teaching materials, ensuring the development of economics teaching and research in universities can plays a catalytic role in the economic development.

\section{Acknowledgement}

Project Name: "Construction Project of Commercial and Public Training Center Based on the Integration of General Capabilities of Enterprise Management"

\section{References:}

[1] Suo Shan. Reflections on the Teaching Reform of Economics Based on Micro-Class[J]. Education and Teaching Forum, 2018, (25). 
[2] Zhang Zhongsheng. Investigation and Analysis of the Current Situation of Economics Education and Teaching in Colleges and Universities [J]. Beijing Education (Higher Education Edition), 2018, (6).

[3] Si Lijuan. On Several Key Points in the Teaching of Economics in Colleges and Universities [J]. Modern Economic Information, 2016, (13)

[4] Liu Yong. The application of the network in the teaching of economics in colleges and universities [J]. Urban Tutor (first half of the month), 2013, (11). 